\title{
The assessment of the usefulness of selected functions in the description of the flow characteristics of a throttle body
}

\begin{abstract}
The paper presents a comparison of selected functions used in the description of the flow characteristics of a throttle body. The purpose of the performed analysis was to select functions that would represent the throttle flow capacity with the smallest possible error. Such characteristics are used in the modeling of the engine op-eration and very often influence the final effect of the mixture composition by e.g. setting a stoichiometric mixture. If, at a set throttle angle the stream of air mass is erratically defined then at the set fuel mass we shall receive an improper exhaust composition, which in modern engine designs is decisive in terms of proper engine operation. Indeed, in a real engine, the ECU based on the oxygen sensor feedback will adjust the fuel mass, but it is far better to double check the process of mixture formation rather than correct the consequences of its improper formation.
\end{abstract}

Keywords: combustion engine, fuel delivery system, throttle body, research

\section{Ocena przydatności wybranych funkcji do opisu charakterystyki przeplywowej przepustnicy}

\begin{abstract}
W artykule przedstawiono porównanie wybranych funkcji stosowanych do opisu charakterystyki przeplywowej przepustnicy. Celem przeprowadzonej analizy było wytypowanie funkcji, która z najmniejszym błędem będzie odwzorowywata przepustowość przepustnicy. Tego typu charakterystyki wykorzystywane sa w modelowaniu działania silnika i bardzo często wplywają na efekt końcowy, np. poprzez zadanie stechiometrycznego składu mieszaniny palnej na sktad spalin. Jeżeli przy założonym kacie otwarcia przepustnicy błędnie zdefiniuje się strumień masy powietrza, to przy założonej masie paliwa otrzymamy nieadekwatny skład spalin, co w obecnych konstrukcjach jest czynnikiem decydujacym dla poprawnej pracy silnika. Wprawdzie w rzeczywistym silniku uktad elektronicznego sterowania w oparciu o odczyt sygnału czujnika obecności tlenu w spalinach dokona korekty masy paliwa w pętli sprzężenia zwrotnego, lecz lepiej jest prowadzić proces tworzenia mieszaniny palnej poprawnie niż korygować jego skutki.
\end{abstract}

Słowa kluczowe: silnik spalinowy, układ zasilania, przepustnica, badania

\section{Introduction}

In the simulation research (modeling) of any actual process i.e. a process that takes place in the intake system of an engine an appropriate nominal model has to be assumed that in relation to the physical phenomena is called a physical model. The next step is the formal mathematical description of the phenomena leading to the development of a mathematical model with the possibility of obtaining of the results with the use of computers (simulation).

Currently, there is a plethora of available software allowing a flow simulation as shown in [8]. The mathematical models that are used for this process can be divided into: zero-dimensional, mono-dimensional and multidimensional. Very often, in less complex models, where own components are implemented (equations) it is necessary to know the characteristics of individual components, whose adequacy to the model description significantly influences the quality of the simulation results $[1,9]$. That is why an attempt has been made to compare the usefulness of the selected functions in the description of the flow characteristics of a throttle body.

\section{The object and methodology of the investigations}

The objects of the investigations were three throttle bodies different in terms of design. The technical specifications and the applications of the throttle bodies have been presented in [10]. The dimension shave been shown in Table 1.

\section{Wstęp}

W badaniach symulacyjnych (modelowaniu) każdego rzeczywistego procesu, a więc i procesów zachodzących w układzie dolotowym silnika, podstawowym zagadnieniem jest przyjęcie odpowiedniego modelu nominalnego, który w odniesieniu do zjawisk fizycznych jest nazywany modelem fizycznym. Następnym krokiem jest formalny opis matematyczny przyjętych zjawisk, prowadzący do powstania modelu matematycznego z możliwością uzyskania wyników przy użyciu techniki komputerowej (symulacji).

Obecnie „rynek” oprogramowania pozwalającego przeprowadzić symulacje przepływu jest dość obszerny, co przedstawiono w pracy [8]. Modele matematyczne, które są do tego celu wykorzystywane można podzielić na: zerowymiarowe, jednowymiarowe i wielowymiarowe. Bardzo często w modelach mniej skomplikowanych, w których implementuje się własne komponenty (równania) niezbędna jest znajomość charakterystyk poszczególnych elementów składowych, których adekwatność do opisu modelowego procesu w istotny sposób wpływa na jakość wyników symulacji $[1,9]$. Dlatego podjęto próbę porównania przydatności wybranych funkcji do opisu charakterystyki przepływowej przepustnicy.

\section{Przedmiot i metodyka badań}

Przedmiotem badań były trzy różniące się konstrukcyjnie podzespoły przepustnic. Opis techniczny oraz ich 
In order to determine the flow capacity of the investigated throttle bodies a dynamic method was used consisting in determining of the courses of the pressure changes in time in the measurement chamber (a mass flow meter), where in the flow trajectory, triggered by the difference in pressures (chamber vs. ambient pressure), an obstacle in the form of an adjustable throttle body is provided. The methodology has been described in detail in [10]. In the case of the investigation of pneumatic systems a method of determining of flow losses [3] is also used or the method using the mass flow meters ISO 6358 [4], but it is applied only in pipelines and brake systems. zastosowanie przedstawiono $\mathrm{w}$ pracy [10]. Podstawowe wymiary zestawiono w tabeli 1 .

Do wyznaczenia przepustowości przepustnicy w badaniach wykorzystano metodę dynamiczną, polegającą na wyznaczaniu przebiegów czasowych zmian cieśnienia w zbiorniku pomiarowym (będącym przepływomierzem), gdzie na drodze przepływu wywołanego różnicą ciśnień zbiornik-otoczenie zadaje się zakłócenie w postaci przepustnicy z regulowanym stopniem uchylenia. Metodę badań szczegółowo opisano w pracy [10]. W przypadku badań układów pneumatycznych wykorzystywana jest również metoda wyznaczania współczynnika strat przepływu [3] lub

Table 1. Dimensions of the throttle bodies

Tabela 1. Podstawowe wymiary badanych przepustnic

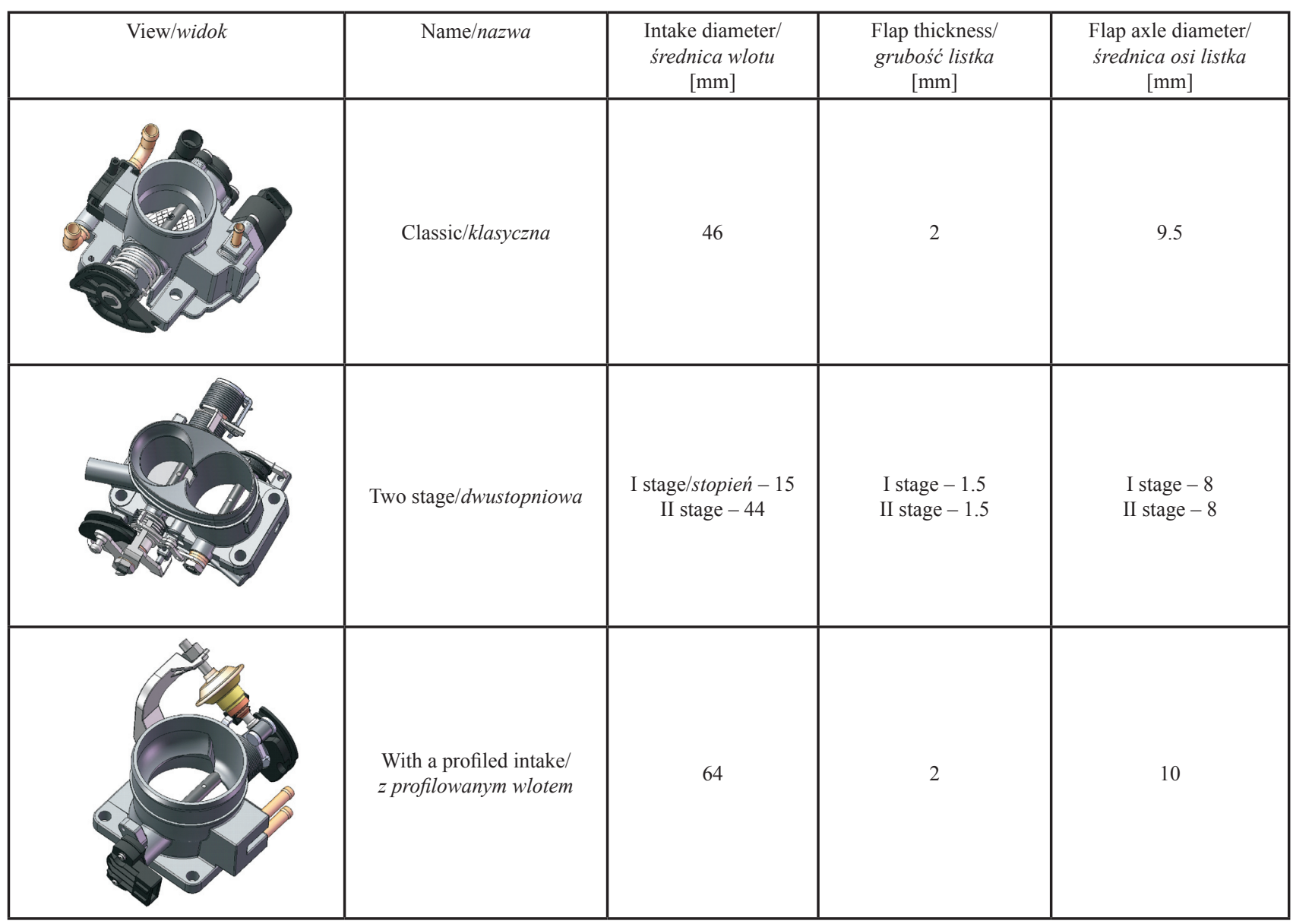

The measurements were carried out at different throttle positions. In the identification process a model of adiabatic air filling of a constant volume chamber has been used (mass flow meter):

$$
\frac{\mathrm{dp}_{\mathrm{d}}}{\mathrm{dt}}=\frac{\kappa \cdot \mathrm{R} \cdot \mathrm{T}}{\mathrm{V}_{\mathrm{z}}} \cdot\left((\mu \mathrm{A})_{\mathrm{d}} \cdot \frac{\mathrm{p}_{\mathrm{a}}}{\mathrm{R} \cdot \mathrm{T}} \cdot \mathrm{v}_{\max } \cdot \varphi_{\max }(\sigma) \cdot \varphi(\sigma)\right)
$$

In the Matlab environment the experimental courses were compared with the model ones and, based on the comparison, flow capacity $(\mu \mathrm{A})_{d}$ was determined with the use of non- metoda wykorzystująca przepływomierze ISO 6358 [4], lecz znajduje ona zastosowanie w odniesieniu do rurociągów i układów hamulcowych.

Pomiary prowadzono przy różnych położeniach przepustnicy. W procesie identyfikacji wykorzystano model adiabatycznego napełniania powietrzem stałej objętości zbiornika pomiarowego (przepływomierza) - równanie (1).

W środowisku Matlab porównywano przebiegi doświadczalne $\mathrm{z}$ modelowymi i na tej podstawie wyznaczano przepustowość $(\mu \mathrm{A})_{\mathrm{d}}$, wykorzystując regresję nieliniową, minimalizując metodą Neldera-Meada funkcję (2). 
linear regression, minimizing the function by the method of Nelder-Mead:

$$
\mathrm{FPE} 1=\frac{\mathrm{m}+1}{\mathrm{~m}(\mathrm{~m}-1)} \sum_{\mathrm{i}=1}^{\mathrm{m}}\left(\mathrm{p}_{\mathrm{d}}-\mathrm{p}_{\mathrm{m}}\right)^{2}
$$

The authors based their creation of the model courses on solving of a differential equation (1) with the Runge-Kutty method.

Determining of flow capacity $(\mu \mathrm{A})$ as a whole without a split into flow coefficient $\mu$ and instantaneous flow area A was done because in the available literature an analytical determination of the instantaneous flow area constitutes a problem. The instantaneous flow area divides into sections depending on the throttle angle $[9,12]$. This requires an addition of a correction coefficient that could be reflected in flow coefficient $\mu$. Adjusting both $\mu$, and A the authors decide to determine the flow capacity $(\mu \mathrm{A})$.

\section{Results and analysis}

Similarly to the identification of $(\mu \mathrm{A})_{\mathrm{d}}$ from the time courses as detailed in [10] in the throttle flow characteristics analysis the same procedures were used i.e. non-linear regression method, minimizing the FPE1 index with the simplex method of Nelder-Mead:

$$
\mathrm{FPE} 1=\frac{\mathrm{m}+1}{\mathrm{~m}(\mathrm{~m}-1)} \sum_{\mathrm{i}=1}^{\mathrm{m}}\left((\mu \mathrm{A})_{\mathrm{d}}-(\mu \mathrm{A})_{\mathrm{m}}\right)^{2}
$$

The index FPE2 representing the average error has been determined:

$$
\mathrm{FPE} 2=\frac{1}{\mathrm{~m}} \sum_{\mathrm{i}=1}^{\mathrm{m}}\left|(\mu \mathrm{A})_{\mathrm{d}}-(\mu \mathrm{A})_{\mathrm{m}}\right|
$$

And the maximum FPE3 error value:

$$
\mathrm{FPE} 3=\operatorname{MAX}\left|(\mu \mathrm{A})_{\mathrm{d}}-(\mu \mathrm{A})_{\mathrm{m}}\right|
$$

An additional criterion of evaluation of the compatibility of the actual and model values was the non-linear regression coefficient adjusted to the degrees of freedom i.e. related to the number of significant coefficients of model and the number of points on the identified curve:

$$
\mathrm{R}^{2}=1-\frac{\mathrm{m}-1}{\mathrm{~m}-1} \cdot \frac{\sum_{\mathrm{i}=1}^{\mathrm{m}}\left((\mu \mathrm{A})_{\mathrm{d}}-(\mu \mathrm{A})_{\mathrm{m}}\right)^{2}}{\sum_{\mathrm{i}=1}^{\mathrm{m}}\left((\mu \mathrm{A})_{\mathrm{d}}-\overline{(\mu \mathrm{A})_{\mathrm{m}}}\right)^{2}}
$$

Out of many functions those that are used most frequently in the simulation tests were selected $[2,7,12]$ and compared to the static functions [13] as the flow characteristics of the throttle is close to normal distribution.
W tworzeniu przebiegów modelowych opierano się każdorazowo na rozwiązywaniu równania różniczkowego (1) metodą Rungego-Kutty.

Wyznaczanie przepustowości ( $\mu \mathrm{A})$ jako całości bez rozbicia na współczynnik przepływu $\mu$ i pole chwilowego przepływu A podyktowane było tym, iż w dostępnej literaturze analityczne wyznaczenie chwilowego pola przepływu sprawia duży problem. Pole chwilowego przepływu dzieli się na przedziały, w zależności od kąta otwarcia przepustnicy $[9,12]$. Wymaga to wprowadzenia współczynnika korekcyjnego, który mógłby również znaleźć odzwierciedlenie we współczynniku przepływu $\mu$. Korygując zarówno $\mu$, jak też A zdecydowano się na wyznaczanie przepustowości $(\mu \mathrm{A})$.

\section{Wyniki badań i analiza}

Podobnie jak w przypadku identyfikacji $(\mu \mathrm{A})_{\mathrm{d}} \mathrm{z}$ przebiegów czasowych, co szczegółowo przedstawiono w pracy [10], również w analizie charakterystyk przepływowych przepustnic wykorzystano te same procedury, tj. metodę regresji nieliniowej, minimalizując metodą sympleksu Neldera-Meada wskaźnik FPE1 - równanie (3).

Wyznaczano wskaźnik FPE2 reprezentujący błąd średni (4) oraz maksymalną wartość błędu FPE3 (5).

Dodatkowym kryterium oceny stopnia dopasowania wartości rzeczywistych i modelowych był współczynnik regresji nieliniowej skorygowany na stopnie swobody, tj. odniesiony do liczby istotnych współczynników modelu i liczby punktów identyfikowanej krzywej (6).

Spośród wielu funkcji wybrano te stosowane najczęściej $\mathrm{w}$ badaniach symulacyjnych $[2,7,12]$ i porównano je $\mathrm{Z}$ funkcjami statystycznymi [13], gdyż charakterystyka przepływowa przepustnicy zbliżona jest do charakteru rozkładu normalnego.

Wykorzystane zależności przedstawiono w tabeli 2, gdzie zestawiono również wartości współczynników funkcji, dla których uzyskano minimalną wartość wskaźnika FPE1.

W porównaniu pominięto funkcję przedstawioną przez Idelchika [5] z uwagi na pewne niedoskonałości w odwzorowaniu pełnego zakresu, związanym ze znacznymi rozbieżnościami w zakresie otwarcia maksymalnego, jak też funkcję przedstawioną przez Igarashiego, Inagakiego [6] z uwagi na znaczne skomplikowanie zależności, poprzez uwzględnienie wartości liczby Reynoldsa, co również sygnalizowano w pracy [11].

Analizując charakterystyki wszystkich trzech różniących się konstrukcyjnie przepustnic (rys. 1), można zauważyć, że permanentnie wykorzystywane w badaniach symulacyjnych funkcje Aquino [2] i Nyberga [7] (por. tab. 1) nie oddają w pełni charakterystyki przepływowej żadnej z nich, szczególnie w czasie ich pełnego otwarcia. Lepszą zgodność modelu z rzeczywistością reprezentuje funkcja przedstawiona przez Wendekera [12], w przypadku której błąd średni jest o ok. $30 \%$ mniejszy niż w dwóch poprzednich.

Zaproponowana funkcja Bella [13] ilościowo przedstawia się podobnie jak Wendekera [12], przy podobnym skomplikowaniu postaci.

Zaczerpnięte ze statystyki, wykorzystywane również w modelowaniu rozmytym układów elektronicznych funkcje 
Table 2. Functions and the values of the coefficients

Tabela 2. Zestawienie funkcji wraz z wartościami współczynników

\begin{tabular}{|c|c|c|c|c|c|}
\hline \multirow[t]{2}{*}{ Item } & \multirow[t]{2}{*}{ Name/nazwa } & \multirow[t]{2}{*}{ Function/postać funkcji } & \multicolumn{3}{|c|}{ Values of the coefficients/wartości wspótczynników } \\
\hline & & & Classic/klasyczna & $\begin{array}{c}\text { Two stage/ } \\
\text { dwuprzelotowa }\end{array}$ & $\begin{array}{c}\text { With a profiled intake/ } \\
\text { z profilowanym } \\
\text { wlotem }\end{array}$ \\
\hline 1 & Aquino [2] & $\mu \mathrm{A}(\alpha)=\mu \mathrm{A}_{\max } \cdot(\mathrm{a}-\cos \alpha)$ & $\mathrm{a}=1.05098$ & $\mathrm{a}=1.01445$ & $\mathrm{a}=1.02461$ \\
\hline 2 & Bell [13] & $\mu \mathrm{A}(\alpha)=\frac{\mu \mathrm{A}_{\max }}{1+\left(\frac{\alpha-\mathrm{a}}{\mathrm{b}}\right)^{2}}$ & $\begin{array}{l}\mathrm{a}=1.46781 \\
\mathrm{~b}=0.45077\end{array}$ & $\begin{array}{l}\mathrm{a}=1.47435 \\
\mathrm{~b}=0.39253\end{array}$ & $\begin{array}{l}\mathrm{a}=1.47435 \\
\mathrm{~b}=0.39253\end{array}$ \\
\hline 3 & Gauss $1[13]$ & $\mu \mathrm{A}(\alpha)=\mu \mathrm{A}_{\max } \cdot \mathrm{e}^{\mathrm{a}(\mathrm{b}-\alpha)^{c}}$ & $\begin{array}{l}a=-1.90737 \\
b=1.51537 \\
c=1.67158\end{array}$ & $\begin{array}{l}a=-2.35192 \\
b=1.50876 \\
c=1.60123\end{array}$ & $\begin{array}{l}a=-1.72905 \\
b=1.69297 \\
c=2.79449\end{array}$ \\
\hline 4 & Gauss 2 [13] & $\mu \mathrm{A}(\alpha)=\mu \mathrm{A}_{\max } \cdot \mathrm{e}^{\mathrm{a}\left(\frac{\alpha-\mathrm{b}}{\mathrm{c}}\right)^{2}}$ & $\begin{array}{l}a=-1.20387 \\
b=1.60314 \\
c=0.85072\end{array}$ & $\begin{array}{l}a=-1.08523 \\
b=1.59309 \\
c=0.70462\end{array}$ & $\begin{array}{l}\mathrm{a}=-1.12412 \\
\mathrm{~b}=1.51273 \\
\mathrm{c}=0.67235\end{array}$ \\
\hline 5 & Nyberg [7] & $\mu \mathrm{A}(\alpha)=\mu \mathrm{A}_{\max }(1-\cos (\mathrm{a} \cdot \alpha+\mathrm{b}))$ & $\begin{array}{l}\mathrm{a}=1.00237 \\
\mathrm{~b}=4.35306\end{array}$ & $\begin{array}{c}a=1.12159 \\
b=-6.62452\end{array}$ & $\begin{array}{c}\mathrm{a}=1.12005 \\
\mathrm{~b}=-4.77014\end{array}$ \\
\hline 6 & Wendeker [12] & $\mu \mathrm{A}(\alpha)=\mu \mathrm{A}_{\max }\left(1-\mathrm{e}^{\left.\mathrm{a}\left(\frac{\alpha}{\mathrm{b}}\right)^{\mathrm{c}}\right)}\right.$ & $\begin{array}{l}a=-0.17332 \\
b=0.59543 \\
c=3.05501\end{array}$ & $\begin{array}{l}a=-0.66329 \\
b=1.01068 \\
c=3.90499\end{array}$ & $\begin{array}{l}\mathrm{a}=-0.11076 \\
\mathrm{~b}=0.60057 \\
\mathrm{c}=3.82377\end{array}$ \\
\hline
\end{tabular}

The used relations have been shown in Table 2 along with the values of the function coefficients for which the minimum value of the FPE1 was obtained.

In the comparison the function presented by Idelchik [5] has been omitted due to the shortcomings in the represen-
Gaussa 1 i 2 [13], ilościowo charakteryzują się najlepszą interpolacją w odniesieniu do charakterystyki przepływowej każdej z przepustnic, o czym świadczą wartości współczynników (tab. 3 , rys. 2).
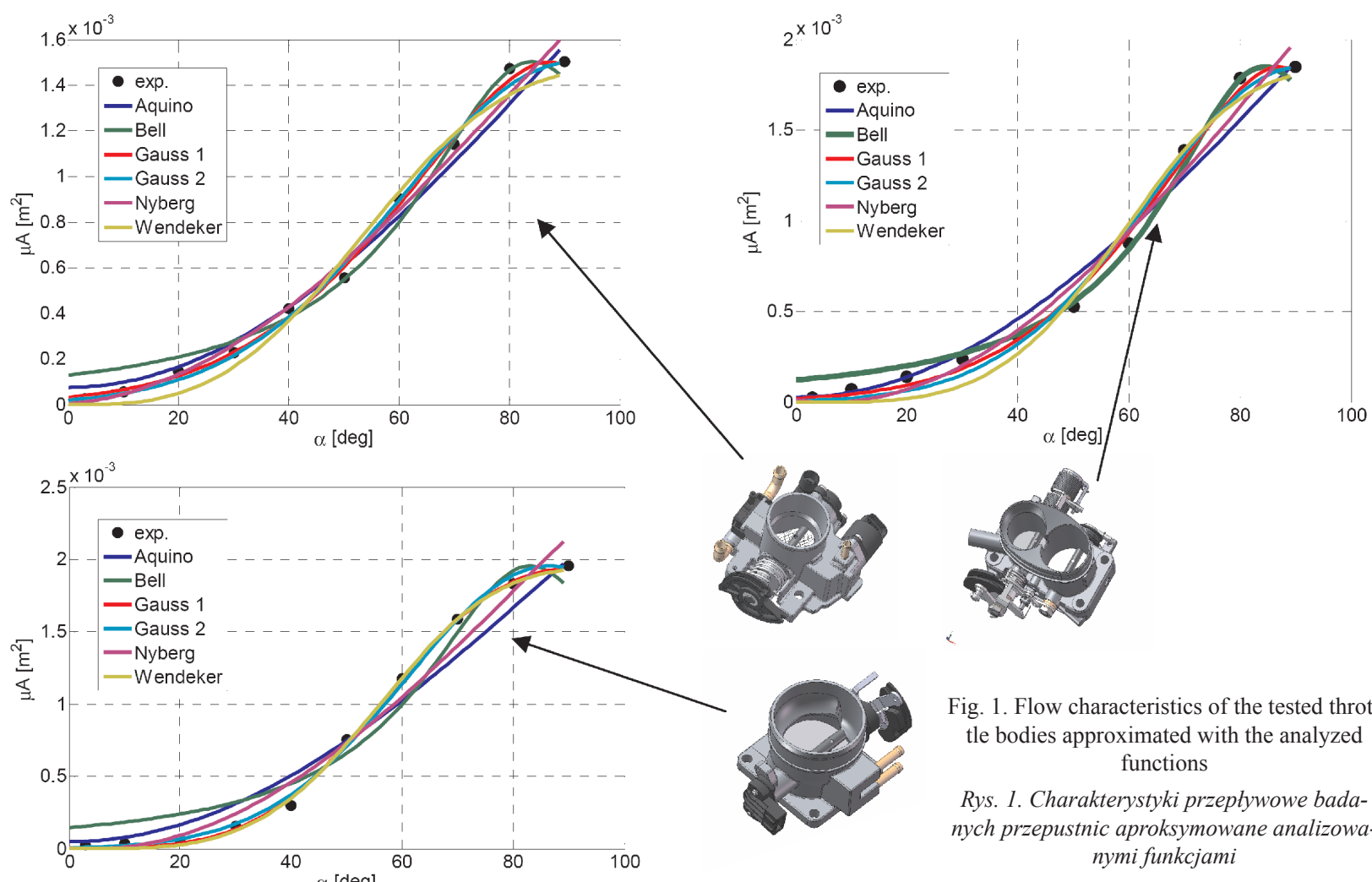

Fig. 1. Flow characteristics of the tested throttle bodies approximated with the analyzed functions

Rys. 1. Charakterystyki przeplywowe badanych przepustnic aproksymowane analizowanymi funkcjami 
tation of the full range related to significant discrepancies in the maximum opening as well as the function presented by Igarashi, Inagaki [6] due to the complexity of the relations due to the inclusion of the Reynolds number which was also indicated in paper [11].

Analyzing the characteristics of all three differently designed throttle bodies (Fig. 1) we can see that the Aquino [2] and Nyberg [7] (see Tab. 1) functions permanently used on the tests do not fully reflect the flow characteristics of any of them when fully opened. A better model compatibility with the reality represents the function presented by Wendeker [12] for which the average error is approximately $30 \%$ lesser than in the two previous ones.

The proposed Bell function [13] is similar to the Wendeker function [12] in terms of quantity at a similar form complexity.

The Gauss functions 1 and 2 [13], taken from the statistics, used in fuzzy modeling of electronic systems in terms of quantity are characterized with the best interpolation in relation to the flow characteristics of any of the throttle bodies, which is confirmed by the value of the coefficients (Tab. 3, Fig. 2).

Particularly the Gauss function 1 [13] is characterized with a half lower average error and the average value of the non-linear regression coefficient was above 0.997 .
Table 3. Quantitative assessment of the identification Tabela 3. Ocena ilościowa identyfikacji

\begin{tabular}{|c|c|c|c|c|c|}
\hline \multirow{2}{*}{ Item } & Name/nazwa & \multicolumn{4}{|c|}{ Values of the coefficients/wartości wspótczynników } \\
\hline & & FPE1 [m $\left.{ }^{4}\right]$ & FPE2 $\left[\mathrm{m}^{2}\right]$ & FPE3 [m²] & $\mathrm{R}^{2}[-]$ \\
\hline 1 & Aquino [2] & $8.21 \mathrm{E}-06$ & $8.57 \mathrm{E}-05$ & $21.37 \mathrm{E}-05$ & 0.973643 \\
\hline 2 & Bell [13] & $7.67 \mathrm{E}-06$ & $8.31 \mathrm{E}-05$ & $13.13 \mathrm{E}-05$ & 0.981768 \\
\hline 3 & Gauss $1[13]$ & $1.33 \mathrm{E}-06$ & $3.22 \mathrm{E}-05$ & $5.72 \mathrm{E}-05$ & 0.997944 \\
\hline 4 & Gauss $2[13]$ & $2.33 \mathrm{E}-06$ & $3.63 \mathrm{E}-05$ & $7.97 \mathrm{E}-05$ & 0.995995 \\
\hline 5 & Nyberg [7] & $7.56 \mathrm{E}-06$ & $7.37 \mathrm{E}-05$ & $16.25 \mathrm{E}-05$ & 0.983427 \\
\hline 6 & Wendeker [12] & $5.33 \mathrm{E}-06$ & $5.47 \mathrm{E}-05$ & $10.34 \mathrm{E}-05$ & 0.991066 \\
\hline
\end{tabular}

Szczególnie funkcja Gauss 1 [13] charakteryzuje się o połowę mniejszym błędem średnim, z kolei wartość średnia współczynnika regresji nieliniowej wyniosła powyżej 0,997 .

\section{Podsumowanie}

Przedstawione porównanie funkcji miało na celu wytypowanie tej, która $\mathrm{z}$ najmniejszym błędem opisze charakterystyki przepływowe wybranych typów przepustnic. Jak widać, stosowane w modelowaniu funkcje Aquino [2],
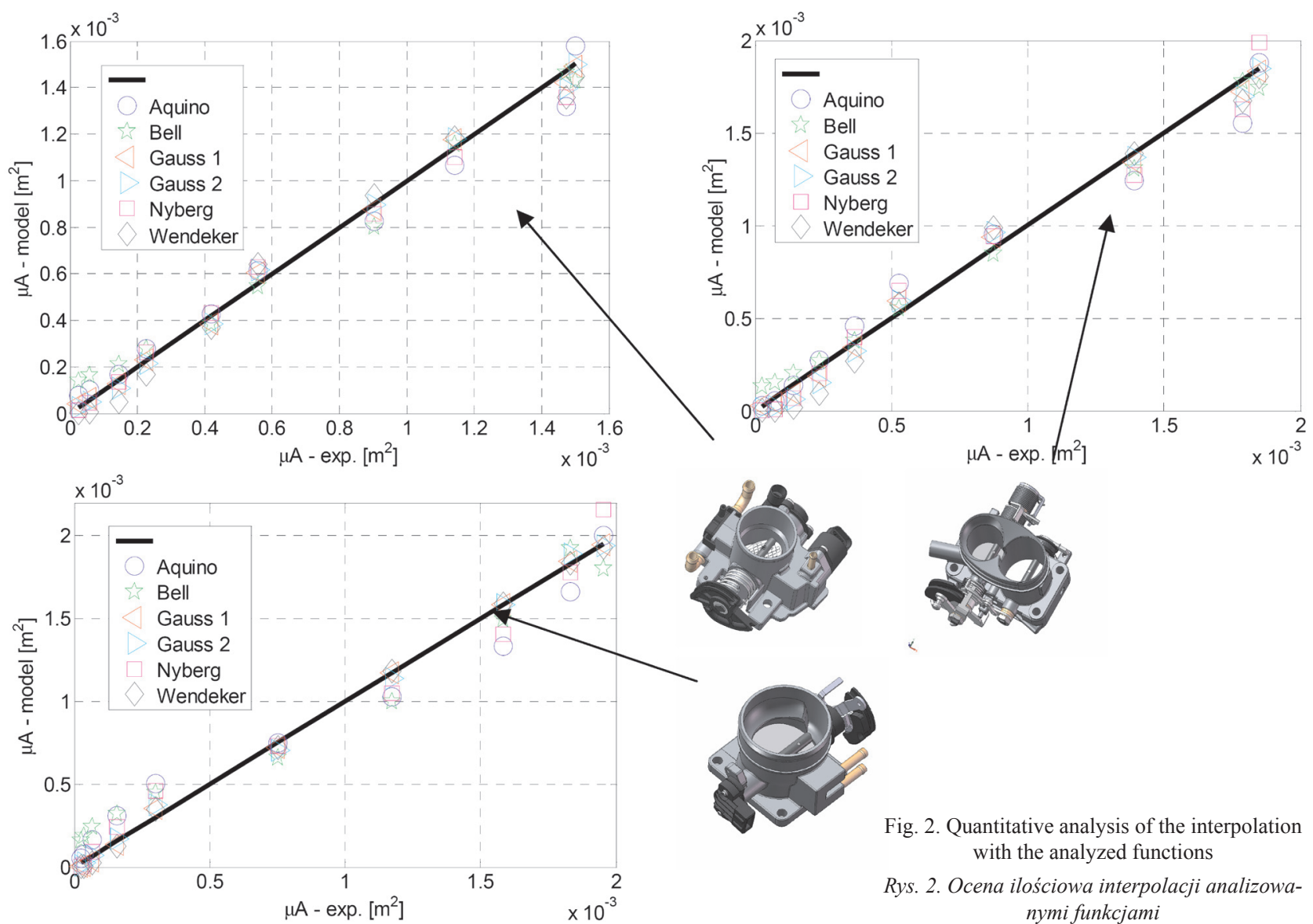

Fig. 2. Quantitative analysis of the interpolation with the analyzed functions

Rys. 2. Ocena ilościowa interpolacji analizowanymi funkcjami 


\section{Conclusions}

The presented comparison of the functions aimed at selecting the one that would describe the flow characteristics of the selected throttle bodies with the smallest possible error. As we can see the Aquino [2], Nyberg [7] and Wendeker [12] functions used in modeling allow a description of the flow properties, though simplified. The proposed static functions, Gauss 1 [13] in particular allowed an obtaining of an approximately $50 \%$ lesser average error. The main criterions in the comparison were the values of the coefficients not the complexity of the model structure.
Nyberga [7] i Wendekera [12] pozwalają na opis właściwości przepływowych, lecz z pewnym uproszczeniem. Zaproponowane funkcje statystyczne, szczególnie Gauss 1 [13], pozwoliły na otrzymanie o ok. 50\% mniejszego błędu średniego. Głównym kryterium w porównaniu były wartości współczynników, a nie skomplikowanie struktury modelu.

Paper reviewed

\section{Nomenclature/Skróty i oznaczenia}

A free flow area/pole swobodnego przeptywu $\left[\mathrm{m}^{2}\right]$

FPE1 index - prediction error/wskaźnik-bład predykcji $\left[\mathrm{Pa}^{2}\right]$

FPE2 average error/btad średni $[\mathrm{Pa}]$

FPE3 maximum error/bład maksymalny $[\mathrm{Pa}]$

R2 non-linear regression coefficient, adjusted to the degrees of freedom/wspótczynnik regresji nieliniowej, poprawiony na stopnie swobody

1 a number of significant model coefficients/liczba istotnych wspótczynników modelu

$\mathrm{m}$ number of points of the identified curve/liczba punktów identyfikowanej krzywej

$\mathrm{p}_{\mathrm{a}} \quad$ ambient pressure/ciśnienie atmosferyczne $[\mathrm{Pa}]$

$\mathrm{p}_{\mathrm{d}} \quad$ measurement chamber pressure determined experimentally/ciśnienie w zbiorniku pomiarowym wyznaczone droga doświadczalna $[\mathrm{Pa}]$

$\mathrm{p}_{\mathrm{m}} \quad$ measurement chamber pressure determined through a model/ciśnienie $w$ zbiorniku pomiarowym wyznaczone droga modelowa $[\mathrm{Pa}]$

$\mathrm{R}$ gas constant for air/stata gazowa, dla powietrza $\mathrm{R}=287.9[\mathrm{~J} /(\mathrm{kg} \mathrm{K})]$

$\mathrm{T} \quad$ air temperature before obstacle/temperatura powietrza przed oporem $[\mathrm{K}]$
$\mathrm{V}_{\mathrm{N}}$ measurement chamber volume/objętość zbiornika pomiarowego $\left[\mathrm{m}^{3}\right]$

$\mathrm{v}_{\mathrm{m}} \quad$ sound dissipation velocity in a stationary gas/prędkość rozchodzenia się dźwięku wieruchomym gazie $\mathrm{v}_{\mathrm{m}}=\sqrt{\kappa \cdot \mathrm{R} \cdot \mathrm{T}}$ adiabate/wyktadnik adiabaty $\kappa=1.405$

$\mu \quad$ flow coefficient/współczynnik przeptywu

$\mu \mathrm{A}_{\mathrm{d}} \quad$ flow capacity determined experimentally/przepustowość wyznaczona droga doświadczalna $\left[\mathrm{m}^{2}\right]$

$\mu \mathrm{A}_{\mathrm{m}} \quad$ flow capacity determined through calculation/przepustowość wyznaczona droga obliczeniowa $\left[\mathrm{m}^{2}\right]$

$\varphi(\sigma)$ dimensionless flow function, form as per Miatluk-Avtuszko, adjusted by the author/bezwymiarowa funkcja przepływu, postać wg Miatluka-Avtuszko, skorygowana przez autora $[10], \varphi(\sigma)=1.07 \cdot \frac{1-\sigma}{1.07-\sigma}$

$\varphi_{\max }(\sigma)$ maximum value of the St' Venant and Wantzel function/ wartość maksymalna funkcji St Venanta i Wantzela

$\varphi_{\max }=\sqrt{\left(\frac{2}{\kappa+1}\right)^{\frac{\kappa+1}{\kappa-1}}}$

\section{Bibliography/Literatura}

[1] Aono T., Kowatari T.: Thorttle - Control Algorithm for Omproving Engine Response Based on Air - Intake Model and Thorttle - Responnse Model, IEEE Transations on Industrial Electronics, Vol. 53, No. 3, 2006.

[2] Aquino C.S.: Transient A/F Control Characteristics of the 5 litre Central Injection Engine, SAE Paper 81094, 1981.

[3] Dymenko S.K., Kurilenko A.A., Kolesnikov S.S.: Study of the Drag of a Thorttle in the Film Boling of a Cryogenic Liquid Flowing in a Horizontal Pipe, Plenum Publishing Corporation, 1983.

[4] Kuroshita K., Sekiguhi Y., Oshiki K., Oneyama N.: Development of new test method for flow-rate characteristics of pneumatic components, Power Transmission and Motion Control, University of Bath, 2004.

Mr. Dariusz Szpica, DEng. - doctor in the Faculty of Mechanical Engineering at Bialystok University of Technology.

Dr inż. Dariusz Szpica - adiunkt na Wydziale Mechanicznym Politechniki Białostockiej.

e-mail:dszpica@pb.bialystok.pl
[5] Idelchik I.E.: Handbook of Hydraulic Resistance ( $3^{\text {rd }}$ Ed.), Chapter 9, New York, Begell House, 1996.

[6] Igarashi T., Inagaki S.: Hydraulic Losses of Flow Control Devices in Pipes, JSME International Journal, Series B, 38, 3, 1995.

[7] Nyberg M.: Model Based Falut Diagnosis - Methods, Theory, and Automotive Engine Applications, Linus \& Linnea AB, ISBN 91-7219-521-5, 1999.

[8] Rawski F., Szpica D.: Symulacyjne metody badań układów dolotowych tłokowych silników spalinowych, Przegląd Mechaniczny nr 2, 2005.

[9] Scherer M., Arndt C., Loffeld O.: Influence of Manifold Pressure Pulsations to Mean Value Models in Air Fuel Ratio Control, MED-5-1997.

[10] Szpica D.: Badanie przepustowości podzespołów przepustnic silników spalinowych o ZI, Silniki Spalinowe nr 2, 2009.

[11] Wojtkowiak J., Oleśkowicz-Popiel Cz.: Investigations of Butterfly Control Valve Flow Characteristics, Fundations of Civil and Enviromental Engineering, House of Poznan University of Technology, 2006.

[12] Wendeker M.: Sterowanie napełnieniem w silniku samochodowym, Wyd. Lubelskiego Towarzystwa Naukowego, Lublin 1999.

[13] http://powerelectronics.tkk.fi/education/s8127/ex.pdf, 2008. 